\title{
SEMIOTIC THEORY OF MALAM BAINAI DELIVERING IN MINANGKABAU WEDDING CEREMONY
}

\author{
Annisa Karmila ${ }^{1}$, Mayasari, S.Pd, M.Si ${ }^{2}$ \\ English Department, Fakultas Bahasa dan Komunikasi, Universitas Harapan Medan \\ Jalan Imam Bonjol, No.35 Medan, 20151, Sumatera Utara-Indonesia
}

\begin{abstract}
The problem of the study in this research is: how is the procedure for the Malam Bainai process at the Minangkabau community wedding ceremony and what is the meaning contained in the implementation of the Malam Bainai at the Minangkabau community wedding ceremony. The research design used is a qualitative descriptive research method by using Pierce's theory. Then, the informants of this research are people who understand Minangkabau cultures, such as Masters of art and culture who graduated from the University of arts in Padang Panjang, overseas arts, and culture teachers from Padang Panjang, and people who are members of the Minangkabau community in Medan City. The results showed that the Malam Bainai procedure consisted of four series, namely Bamandi, Meniti kain kuniang, Malam Bainai, and Bakameh-kameh. The meaning of the Malam Bainai ceremony is carried out as a form of cultural heritage that has been carried out from generation to generation and as a form of releasing girls from their parents to become brides and companions in other people's lives.
\end{abstract}

Keywords: Linguistics, Semiotics, Malam Bainai, Minangkabau Wedding Ceremony 


\section{Introduction}

Each region in Indonesia has specific cultural and ethnic characteristics in its various cultural practices. Starting from the custom of receiving guests, customary procedures for the funeral process to the marriage custom. Every ethnicity in Indonesia has a variety of different cultural procedures, from Sabang to Merauke. Therefore, Indonesia has thousands of ethnicities in each province or region. More profoundly, culture is a human taste, creativity, and initiative, so it is called culture for the results of that culture. Culture is a precious asset because, in addition to being a characteristic of an area, it is also a symbol of a nation or region (Oktora, 2017: 01).

Culture has several universal elements in which several types of culture are often applied by humans in their daily lives, both from very traditional rural communities and complex modern societies. The elements of this culture include religious systems and religious ceremonies, organizational and social systems, knowledge systems, languages, arts, livelihood systems, systems of marriage procedures, and technology and equipment systems. The composition of these cultural elements in Indonesia's ethnicities is mostly irreversible and is still being carried out by the people (Koentjaraningrat, 2007: 03).

Culture is also identical and cannot be separated from tradition. Culture is usually a tradition that is always carried out with the provisions and procedures of each ethnic group in Indonesia. This tradition becomes a culture. It is systematically carried out from generation to generation from the past to the present. Tradition itself is a comprehensive system, which consists of aspects that give meaning to speech practices, ritual practices, and various other types of behavior from humans or some humans who take action with one another (Mursal Esten in Oktora, 2017: 03 ).

The custom or custom that generally many ethnic groups in Indonesia do or always do in culture and have different processes and procedures for wedding ceremonies is wearing henna on the couple who will become the bride and groom. Most of the ethnic groups in Indonesia have different customs and traditions in using the henna. However, in every marriage in Indonesia, most of them always use the tradition of wearing henna in the wedding process. One of them is the ethnic groups in Minangkabau.

Minangkabau is one of the ethnic groups in Indonesia who speak and uphold Minangkabau customs. This Minangkabau cultural area includes West Sumatra, Riau, Bengkulu, Jambi, the west coast of Sumatra, Aceh and Negeri Sembilan Malaysia. The principles of Minangkabau customs are contained in a brief statement, namely "Adat basandi syarak, syarak basandi Kitabullah" which means custom based on law, law based on the Koran. So it can be concluded that people who have Minangkabau ethnicity are automatically Muslims (Maryelliwati \& Rahmat, 2016: 01).

Adat Minangkabau is a way of life that is based on norms and customs. Budi is based on nature's real conditions because nature is merely a mind that is giving without expecting anything in return. The Minangkabau tradition is a philosophy of life that has become the culture and culture of the Minangkabau. It is also, at the same time, a rule and procedure for the life of the Minangkabau people, which are arranged based on deliberation and consensus and passed down from generation to generation naturally (Oktora, 2017: 03).

One of the traditional ceremonies carried out before the wedding, which is often held by the people of Padang City, is the Malam Bainai traditional ceremony. The implementation of Malam Bainai at the Minangkabau community's wedding ceremony has indeed been passed down from generation 
to generation. The event is held when all preparations have been made. The program will be hosted by a presenter who has been appointed. The first series of events carried out by the anak daro before being paired with henna is the bath-shower event. During this Malam Bainai there are three series of events that the anak daro will pass. The series of events are bamandi-mandi, maniti kain kuniang and Malam Bainai.

In general, the implementation of the Malam Bainai is the installation of henna, which is carried out accompanied by a joint bath. Then the installation of henna on the nails of the bride and groom must be an odd number. Nine at most. A married woman has eight fingers (mother, etek, bako, uni), and a woman is still a virgin. This is because there is hope that a virgin child who pairs henna will soon find a mate. Moreover, one finger is reserved for the bride. Installation of henna is also accompanied by advising the prospective bride and groom. The advice can contain advice to the bride who is getting married, just a joke at the event. The advice can also be made through speech or by using rhymes (Oktora, 2017). The purpose of placing henna on the nails is to inform the public that this woman is no longer a girl but has become a wife. If she walks with a man, the community will know that they are both newlyweds, so there is no negative prejudice against them both.

Based on the first research conducted by Dini Rahma Oktora. 2017, with the title "The Tradition of Malam Bainai at a Traditional Wedding of Padang Pariaman in the District of Rajabasa, Bandar Lampung City." Faculty of Teacher Training and Education. This research aims to know the implementation of Malam Bainai at the traditional wedding ceremony of Padang Pariaman in Rajabasa Raja Village, Rajabasa District, Bandar Lampung City. The research results found that the Malam Bainai was carried out in three stages, namely (1) Basegeh (preparation) stage, namely preparing the equipment and equipment used in the Malam Bainai process moderator, fashion, traditional arts. (2) the implementation stage, namely bamandi-mandi, maniti kain kuniang, and bainai. (3) Bakameh-kameh (closing) stage, giving advice, reciting prayers for the bride and groom and ending with a family event or entertainment.

Mila conducted the second research. 2019, with the title "Minangkabau Community in Surabaya (Study on Changes in Minangkabau Marriage Procedures)." This research aims to find out how the Minangkabau marriage procedures in West Sumatra, find out how the Minangkabau marriage procedures in Surabaya, and find out what changes the Minangkabau marriage procedure in Surabaya. The results of the research prove that 1) Minangkabau marriages in West Sumatra have various kinds of processions which have the meaning of getting married 2) Minangkabau marriages in Surabaya have fewer processions than in West Sumatra 3) there is a combination with the Minangkabau marriage procedures with local customs.

Sylvia, Syahrel \& Mariam conducted the third study. 2014, with the title "Structure of Malam Bainai Presentation at a Wedding in Padang City." This study aims to describe the presentation structure of Bainai Night in a Wedding Ceremony in Kubu Dalam Park Karakah Village, East Padang District, Padang City. This type of research is qualitative with a descriptive analysis approach. The Malam Bainai Procession consists of three main parts: Bamandi-Mandi, Maniti Kain Kuning, and Banai. In the bainai procession, henna is applied by the bako, and the sister of the bride's mother, the wife, uncle of the bride, or the woman's family comes procession.

The fourth research was conducted by Hastuti \& Owari. 2016, with the title "Marriage Culture of the Mining Rantau Community in Jakarta". The purpose of this paper is (1) to describe the views of the Minangkabau people in general on marriage, (2) to describe the implementation of the traditional 
marriage culture of the Minang rantau community in Jakarta, (3) to describe the moral values contained in the marriage culture of the Minang rantau community in Jakarta. The results of the research are (1) the community's view of traditional marriage is a means to strengthen kinship, (2) the implementation of the traditional marriage culture of the Minang community includes several stages, namely: (a) before the implementation ceremony is carried out 1) maresek 2) maminang and batuka tando 3 ) Mahanta, 4) babo, 5) Malam Bainai, 6) manjapuik marapulai and 7) manyambuik at the child's house, which is followed by a marriage contract, (b) the implementation of the marriage ceremony 1) malamar, 2) Akaik nikah, 3) sasarahan, 4 ) pangajian and 5) babaleh application, (c) after the implementation of the marriage ceremony proceed to baralek. (3) The moral values in the Minang Rantau community's marriage culture are values related to divinity, values related to social and individual moral values.

Fazira Sahbani conducted the fifth research. 2017, with the title "Overview of the Traditional Marriage Ceremony and Bridal Makeup in VII Koto Sungai Sariak District, Padang Pariaman Regency." The results showed that the wedding ceremony in VII Koto Sungai Sariak District consisted of three stages: the ceremony before marriage, the ceremony for implementing the marriage and the ceremony after marriage. The pre-wedding ceremony consists of the Bajalan Malam, babaua, batuka tando. The marriage ceremony consists of the marapulai manjapuik, the marriage contract, the baralek day. Meanwhile, the after-marriage ceremony consists of manjalang mintuo, malam patang katangah, baretong, manduo kali, mandoa salamaik. In the implementation of the marriage ceremony, several series are no longer carried out, such as investigating the family to be proposed before the Bajalan malam and Malam Bainai are carried out.

Expressly, it should be noted that the Minangkabau are one of the ethnic groups in Indonesia who speak and uphold Minangkabau customs. This Minangkabau cultural area includes West Sumatra, Riau, Bengkulu, Jambi, the west coast of Sumatra, Aceh and Negeri Sembilan Malaysia. The principles of Minangkabau customs are contained in a brief statement, namely "Adat basandi syarak, syarak basandi Kitabullah" which means custom based on law, law based on the Al-Quran. So it can be concluded that people who have Minangkabau ethnicity are automatically Muslims (Maryelliwati \& Rahmat, 2016: 01).

One of the traditional ceremonies that must be performed before the people of Padang City holds the wedding is the Malam Bainai traditional ceremony. In general, the Malam Bainai implementation is the installation of henna, carried out accompanied by a joint bath. Then the installation of henna on the nails of the bride and groom must be an odd number. Nine at most. Married women (mother, aunt, sister) have eight fingers, and one woman is still a virgin. This is because there is hope that a virgin child who pairs henna will soon find a mate.

Moreover, one finger is reserved for the bride. Installation of henna is also accompanied by advising the prospective bride and groom. This advice can contain advice to the bride who is getting married, just a joke at the event. The advice can also be made through speech or by using rhymes (Oktora, 2017).

Based on this description, the researcher is interested in conducting specific research on the presentation structure and process of the Malam Bainai at the wedding ceremony of the Minangkabau community. For this reason, the author intends to examine the presentation structure of the Malam Bainai procession and analyze the meaning contained in the Malam Bainai process using the C.S. Pierce. 
The purpose of this research is to find out how the procedures for the Malam Bainai process at the Minangkabau community wedding ceremony and to find out how the intent and purpose of the Malam Bainai at the Minangkabau community wedding ceremony.

\section{Method}

The research design used by the researcher is qualitative. According to Sugiyono (2013: 13), qualitative research is a new research method; this is because qualitative research is called research based on the philosophy of postpositivism. Qualitative research can also be naturalistic research because it is carried out in natural conditions or what is said to be a natural setting. Qualitative research views social reality as complex, dynamic, full of meaning and has interactive relationship symptoms. Research is also conducted on natural objects, which develop as they are, not manipulated by researchers, and researchers' presence does not affect the dynamics of these objects.

There were three research participants in this study, who were people who understood Minangkabau customs. The process of analyzing research data was carried out by (1) conducting observations by searching from internet sources for matters related to the Malam Bainai structure at the Minangkabau wedding ceremony starting from data and photo documentation (2) Conducting analysis and findings using C.S. Peirce (3) Draw conclusions and verification.

\section{Result and Discussion}

\section{Procedures for the Implementation of Malam Bainai at the Minangkabau Community Wedding Ceremony}

Based on the results of interviews conducted by researchers with the three research informants, the Malam Bainai process at the Minangkabau community wedding ceremony is divided into several parts, including the following:

Basegeh Process (Preparing for cancellation). Before starting the Malam Bainai process, the whole family will usually prepare all kinds of needs and equipment for the Malam Bainai process. The purpose of all families preparing for the Malam Bainai process is to build a strong sense of cooperation and friendship between the prospective bride's entire family (Anak Daro). In addition to preparing the equipment, the family must also prepare a moderator (someone who understands the procedures for implementing the Malam Bainai tradition) so that implementing the event runs well and is by the norms and rules set from to generation. Clothing or clothes worn by the bride and groom are also not ordinary or everyday clothes. The prospective bride is dressed in a particular outfit called a Tokah shirt and has low edits to carry out this event. Tokah is a kind of shawl wrapped across the chest so that the shoulders and arms are exposed.

The Bamandi-mandi process. In this process, the prospective bride (Anak Daro) will be bathed first by her parents. In ancient times, the prospective bride would take a bath in the river, but in the times, the Bamandi-mandi custom was only practiced at home. In the bathing process, if the prospective bride has a male sibling, the sibling is obliged to accompany her during the bathing process because she is trusted to be the prospective bride's bodyguard. Both parents of the prospective bride carry out the process of the Bamandi-mandi ritual. This symbolizes that the 
parents will bathe their children the last time before the next day, they will be handed over to the prospective bridegroom (husband) of their daughter. Besides, this also symbolizes that the duties and responsibilities of the prospective bride's parents have been completed and will then change hands to their husbands later.

Maniti Kain Kuniang Process. After completing the Bamandi-Mandi process, the bride-to-be (Anak daro) will then be led by her parents walking on a yellow pirated cloth stretching out to the aisle Malam Bainai is held. This symbolizes the bride's journey from childhood to adulthood and symbolizes that this is the last day when both parents deliver and hold their child's hand. Because after this process, the next day, the daughter will belong to someone else. Every cloth passed by the prospective anak daro will be rolled up by two brothers, which means that the marriage he goes through is enough once in his life. After arriving at the place where the child has carried out the Malam Bainai process, the prospective bride will first prostrate an apology to both parents or what is often said in Javanese custom "Sungkeman" form of the daughter's apology to her pregnant parents, caring for them. Moreover, raise the child so that a man will marry him and spend his life serving him the next day. Usually, the process of apologizing is accompanied by traditional Minangkabau flute music and, without words, to absorb the symbolic meaning of this process. In the process of the Maniti Kain Kuniang ceremony, the yellow color used as a base for the prospective bride when walking towards the altar means the yellow color symbolizes the ancestral land of "aianyo janiah, ikannyo jinak, and buminya dingin". Besides that, the yellow color also symbolizes greatness, has laws and laws.

Malam Bainai Process. The implementation of henna is the same as the Bamandi-mandi process. Installation of henna on the prospective bride's nails (Anak Daro) must be an odd number, at most Nine. Married women, such as mothers and other relatives, pair eight fingers and an unmarried woman with one finger. This is done so that the unmarried woman can immediately find a mate. The nine fingers attached to the hands of the bride and groom symbolize that the ten fingers are perfection and perfection belongs only to the creator (Allah SWT). Therefore, when attaching the henna to the prospective bride's fingers, it should not be the ten fingers, but only the nine fingers. Installation of henna to the prospective bride is not just a typical henna installation, but it also contains advice and advice from mothers and relatives regarding the joys and sorrows of marriage and responding well to the marriage can run well. In attaching the henna on the bride-to-be's finger, there are meanings to each finger, including: (1) The thumb symbolizes the appreciation, kindness and praise of the prospective wife to the future husband (2) The index finger symbolizes the potential wife's caution in the act and take a stand, are not arbitrary in their attitude, and do not like their hearts to ask the husband (3) The middle finger symbolizes that the prospective bride must take care and consider the hearts of the prospective in-laws, prospective in-laws, prospective inlaws and people in The husband's family environment (4) The ring finger symbolizes the harmony of the couple in running a married life (5) The little finger means the smallest finger and is located at the very end which symbolizes the hope that the prospective bride can behave, be humble and not arrogant. It is also hoped that the prospective bride will not be left out, left behind by in-laws, prospective in-laws, prospective in-laws and other families.

Bakameh-Kameh (closing) process. After completing the Malam Bainai process, it will be closed by giving general advice to the prospective bride. If the giving of advice is finished, then the prayer is read for the bride, hoping that she can become a happy and eternal family after she is married. After that, the guests will be invited to eat the family provided by the family. 


\section{The meaning contained in the implementation of the Malam Bainai at the Minangkabau community wedding ceremony. In terms of C.S.'s semiotic theory Pierce.}

After describing the procedures for the Malam Bainai process at the Minangkabau wedding ceremony, the researcher will conduct an analysis based on the meaning contained in the process of the wedding ceremony procedure based on C.S. Pierce, among others, are as follows:

Icon. In short, an icon means an object that has a particular mark. The purpose of the icon is to give a message to its original form. In this study, the icon in question is henna attached to the fingers of the prospective bride, where each finger has a meaning and meaning conveyed as a phase of the future bride's domestic life according to the fingers' circumstances, such as the mother. Finger as a guideline that a wife must respect her husband, index finger as a conservative attitude of a wife in taking action, middle finger as a form of respect and respect for the wife to in-laws, in-laws and the husband's family environment, the ring finger as a symbol of household harmony and the little finger as a wife must be able to be kind, humble, modest and not arrogant.

Index. In short, an index is a sign that is causal or has a cause and effect. A sign must have a relationship with an object that results in a causal relationship. In this study, the index referred to is the Malam Bainai process, which is an object that produces cause and effect. The Malam Bainai process is believed to be a sacred ceremony in the Minangkabau community. By carrying out the Malam Bainai ceremony process, it is believed that the prospective bride will avoid the danger of getting married and ready to go to and face the household ark.

Symbol. In summary, symbols are signs that are related to their markers and markers. Through symbols, the marker becomes a reference that has been agreed upon by the markers. In this study, the marker is the process of attaching henna to the prospective bride, while the sign is the community who has hereditary carry out the cultural process as something sacred and must be carried out in the hope that the bride's household will always be in harmony. In terms of legal provisions and regulations, a Minangkabau community does not need to carry out the Malam Bainai ceremony process. However, because their ancestors believed in it, they carry out the cultural process as a belief and obedience from generation to generation. So overall, Malam Bainai is a traditional sacred symbol before a bride performs a wedding ceremony.

Rheme. In short, the rheme is a sign that allows a person to interpret these signs differently. Rheme is a cultural shift and cultural understanding of the Minangkabau people related to implementing the Malam Bainai. In ancient society, the Malam Bainai was a sacred night that must be done so that the prospective bride would avoid problems (refuse reinforcements) the next day and carry out the household ark properly. Whereas in some Minangkabau people today, the Malam Bainai process is a cultural procedure that must be carried out as a form of respect for ancestors or traditional elders, but the meaning of Malam Bainai was understood by people in ancient times as a condition for household life to run well, begins experience a shift. It is because changing people's thinking patterns is more realistic and uses reason and logic.

Dicisign. In short, dicisign is a sign that is by the facts and facts. Related to this research, a sign that is by the fact is that henna in Islam is included in converts. The means that henna has been known and existed since the time of the Prophet Sallallahu 'Alaihi Wasallam. Where initially henna was used as a sign of a Muslim woman, henna was also a symbol of Muslim women's jewelry in ancient times. In its development, but still in the context of ancestors, henna is believed to deter someone 
from the interference of demons or jinn. Based on this, the Minangkabau people believe that henna is a form of beautiful jewelry pinned on the finger of the prospective bride as a Muslim woman and can prevent the prospective bride from witchcraft that can interfere with the course of the wedding process later.

Argument. In summary, an argument is a sign that contains a reason for a subject or object. The Malam Bainai process has been attached as a sacred ceremony and must be performed for the Minangkabau community. The purpose of the Malam Bainai traditional ritual is to apologize from the prospective bride to her parents, siblings, her extended family, and the local community where she lived before she became a wife. Another purpose of holding the Malam Bainai ritual is to ask for blessings from the prospective bride's entire family so that later the marriage she is going through can get smooth and blessings from Allah SWT will not find problems. This primary objective is an argument that has been inherent in the Minangkabau community so that the Malam Bainai ceremony process becomes an obligation for the bride's family to carry it out.

\section{Findings}

The Malam Bainai process carried out by the Minangkabau community also includes elements of religious culture and social system culture elements. It is said to be a religious element because all processes and procedures for implementation must be following Islamic law as a religion that is adhered to and believed. Meanwhile, as an element of the social system because people who belong to the Minangkabau ethnicity feel they have to carry out this process form of respect and respect for their culture, customs and cultural norms that have been taught from their ancestors.

Malam Bainai in the Minangkabau community has become a tradition that regenerates from generation to generation. In simple terms, tradition has been done for a long time and is part of the life of a community group. The Minangkabau people believe that the cultured tradition will be the source of a person's character and character. In the Bainai Night process, several traditions must be carried out as a unit from the Malam Bainai itself, including:

Before carrying out the Malam Bainai, the prospective bride will perform a siraman that has a meaning as a form of purifying and cleansing herself from bad things and sign that this is the last time parents bathe their children.

After carrying out the siraman, the prospective bride will walk on a yellow cloth accompanied by her parents as a form of the last time the parents guide their child to the aisle.

After arriving at the seat (the aisle for Malam Bainai), the prospective bride will apologize to her parents and express her gratitude because until she reaches adulthood and goes to the wedding, the parents have guided, taught, and nurtured the prospective bride.

Only after that enters the process of attaching henna (leaves that give off a red color), which is attached to the prospective bride's fingers. The finger attached is up to the ninth finger because the Minangkabau people believe that the value often is the perfect value and perfection belongs only to Allah SWT. Meanwhile, on each finger that the parents and family attach henna, there is advice on how the bride will face family life.

When finished, it is closed with prayers and prayers as a form of gratitude for the favors and gifts from Allah SWT. 
The traditions described above briefly must be implemented to implement cultural structures that have been carried out from the ancestors of the Minangkabau people. Regarding the function of tradition, the Malam Bainai tradition, which is carried out by the Minangkabau community, is classified into a traditional function as the provision of a collective symbol of identity. The function of the Malam Bainai tradition is a form of belief and a form of loyalty from the Minangkabau people to their ethnicity. By carrying out the Malam Bainai tradition, they have given an identity and a sign that the Malam Bainai is part of their culture.

Overall, the Malam Bainai process is a procedure carried out by the family of the prospective bride which aims as a form of cleansing and purifying a woman before marriage, reminding girls of their parents' services and changes in their lives after marriage and as a form of prayer to Allah SWT so that married girls get a life full of blessings, happiness, harmony, prosperity and can mingle and adjust later when they are at their husband's house or enter into a new environment. Therefore, during the Malam Bainai process, many future brides will hear the form of advice as a provision for knowledge later when she enters the wedding ark.

\section{Conclusion}

The procedure for the Malam Bainai process at the Minangkabau community wedding ceremony is carried out on the prospective bride at her home with four series of events. The Malam Bainai process begins with a series of Bamandi (bathing the bride-to-be) events by both parents and the bride's entire family. Then after the Bamandi process, the prospective bride will perform Maniti kain kuniang (walking on a long yellow cloth to the aisle or seat) accompanied by both parents. After that, the process of using henna starting from the parents, relatives and girls is pinned to the nine fingers of the future bride and groom. Furthermore, the last one is the Bakameh-kameh (talking) process, which contains advice and prayers for the blessing of the prospective bride and groom's household.

The meaning contained in the Malam Bainai process at the Minangkabau wedding ceremony is a form of parental release to the daughter who will become a wife for her husband, where for the last time the parents will bathe their child (the Bamandi process), then guide and hold the child's hand. Their women (Maniti kain kuniang process) pair their daughters' henna and advise marriage and prayers for the bride's marriage blessing.

\section{Reference}

Books:

Koentjaraningrat. 2004. Kebudayaan, Mentalitas Dan Pembangunan. Jakarta: PT. Gramedia Pustaka Utama.

Maryelliwati \& Rahmat, Wahyudi. 2016. Sastra Minangkabau Dan Penciptaan Sebuah Karya. Padang: LPPMPP Isi Padang Panjang.

Sugiyono. 2013. Metode Penelitian Pendidikan: Kualitatif, Kuantitatif Dan R\&D. Bandung: $\quad$ CV. Alfabeta.

\section{Journal/Thesis:}

Fazira, Sahbani. 2017. Tinjauan Tentang Upacara Adat Perkawinan dan Tata Rias Pengantin di Kecamatan VII Koto Sungai Sariak Kabupaten Padang Pariaman. Jurnal Skripsi: Program Studi Tata Rias dan Kecantikan Universitas Negeri Padang. 
Hastuti, Erni \& Oswari, Teddy. 2016. Budaya Pernikahan Masyarakat Minang Rantau di Jakarta. UG Jurnal: Vol.10 No.08.

Mila. 2019. Komunitas Minangkabau di Surabaya (Studi Tentang Perubahan Tata Cara Perkawinan Minangkabau). Skripsi: Fakultas Adab dan Humaniora, Universitas Islam Negeri Sunan Ampel Surabaya.

Sylfia, Syahrer \& Marzam. 2014. Struktur Penyajian Malam Bainai Pada Pesta Perkawinan di Kota Padang. Jurnal Skripsi: FBS. Universitas Negeri Padang.

Oktora, Dini Rahma, et al. 2017. Tradisi Malam Bainai Pada Acara Perkawinan Adat Padang Pariaman Di Kecamatan Rajabasa Kota Bandar Lampung. Jurnal Skripsi: FKIP Unila, Bandar Lampung. 